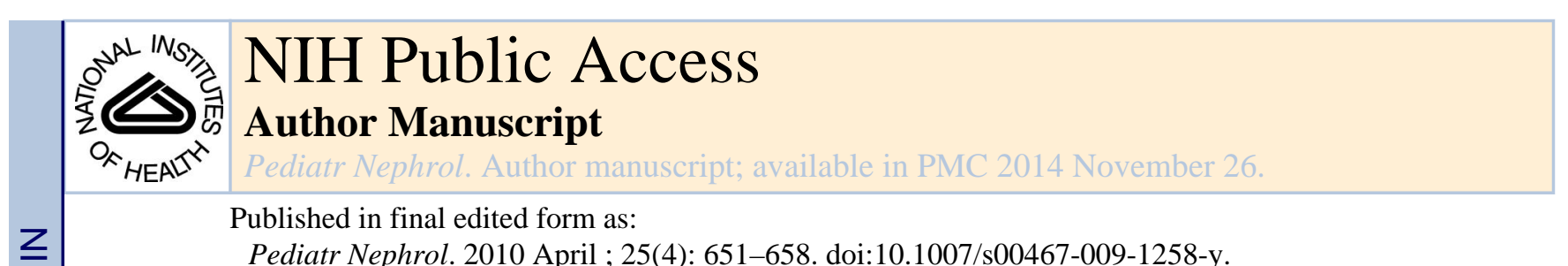

Pediatr Nephrol. 2010 April ; 25(4): 651-658. doi:10.1007/s00467-009-1258-y.

\title{
Gene regulation by growth hormone
}

\author{
Peter Rotwein and \\ Department of Biochemistry and Molecular Biology, Oregon Health \& Science University, 3181 \\ S.W. Sam Jackson Park Rd., Mail code: L224, Portland, OR 97239-3098, USA \\ Dennis J. Chia \\ Division of Endocrinology, Department of Pediatrics, Oregon Health \& Science University, \\ Portland, OR, USA \\ Peter Rotwein: rotweinp@ohsu.edu
}

\section{Abstract}

Since the somatomedin hypothesis of growth hormone $(\mathrm{GH})$ action was first formulated more than 50 years ago, the key roles of both GH and insulin-like growth factor-I (IGF-I) in human growth have been extended to include important effects on tissue maintenance and repair. More recent observations have revealed that this pathway has a negative side, as it has been implicated as a potential contributor to the development of several human cancers and has been linked to diminished lifespan in experimental animals. This brief review focuses on fundamental aspects of gene regulation by $\mathrm{GH}$, as long-term hormonal effects all require changes in gene expression. Topics to be discussed include GH-stimulated signal transduction pathways, mechanisms of gene activation and gene repression by GH, and an analysis of control of IGF-I gene transcription by the GH-stimulated transcription factor, signal transducer and activator of transcription (Stat)5b.

\section{Keywords}

Growth hormone; GH; Growth regulation; Insulin-like growth factor-I; IGF-I; Stat; Stat5b; Gene transcription

\section{Overview}

Since the somatomedin hypothesis of growth hormone $(\mathrm{GH})$ action on growth was first formulated in 1957 [1], much has been learned about the physiology of the GH - insulin-like growth factor-I (IGF-I) - growth axis [2-4]. The central roles of this pathway in normal preand postnatal growth in mammals have been extended to include actions on tissue maintenance, regeneration, and repair in the adult [3, 4]. Along with a clearer definition of positive actions of GH and IGF-I, an appreciation of their potentially harmful effects has been established. The negative roles of excessive $\mathrm{GH}$ on glucose metabolism and on cardiovascular function in acromegaly have been long known [5], as have the pathogenic effects of both GH and IGF-I in proliferative diabetic retinopathy [6]. GH and IGF-I actions

(C) IPNA 2009

Correspondence to: Peter Rotwein, rotweinp@ohsu. edu. 
also have been linked in experimental animals to accelerated aging [7], and IGF-I has been found in epidemiological studies in humans and in experimental models in animals to contribute to several types of cancer [8-10]. Taken together, these studies emphasize the importance of understanding the basic biochemistry and molecular biology of the GH - IGFI pathway in order to modulate its effects on human health and disease.

The focus of this brief review is on fundamentals of gene regulation by GH from both molecular biological and physiological perspectives, with an emphasis on IGF-I as a central target of GH actions. Topics discussed include GH-activated signal transduction pathways, mechanisms of gene activation and gene repression by GH, and an analysis of control of IGF-I gene transcription by the GH-stimulated transcription factor, signal transducer and activator of transcription (Stat) $5 \mathrm{~b}$.

\section{Introduction: GH and IGF-I in growth and tissue maintenance}

It has long been known that both GH and IGF-I are critical for normal human growth [2]. Natural mutations of the GH gene or impaired development of pituitary somatotrophs cause growth deficiency and short stature in children [11], as do mutations in the GH receptor gene $[12,13]$. Mutations that disrupt the IGF-I or IGF-I-receptor genes also lead to profound growth failure that is not responsive to $\mathrm{GH}[14,15]$. Unlike subjects with $\mathrm{GH}$ or $\mathrm{GH}$ receptor deficiency, where growth defects are manifested postnatally, these latter individuals have intrauterine growth failure and exhibit other abnormalities that are consistent with a broader role for IGF-I in both growth regulation and tissue development than as just a mediator of GH actions. Analyses in mice with a targeted deletion of IGF-I or the IGF-I receptor have further established the critical importance of IGF action for normal development in the embryo and fetus [16, 17], whereas knockout of the GH receptor gene has confirmed its key roles in postnatal growth and controlling IGF-I production [18].

GH and IGF-I also play major roles in tissue and organ growth during childhood and in tissue maintenance and repair in the adult. For example, mice lacking the GH receptor have diminished cortical bone formation and trabecular bone turnover that is nearly completely corrected within weeks by systemic infusion of IGF-I [19], demonstrating the significance of the endocrine actions of GH and IGF-I in bone, as initially postulated by the original somatomedin hypothesis [1]. Similarly, engineered loss of IGF-I gene expression in the liver combined with genetic deficiency of the serum carrier molecule acid labile subunit (ALS) [liver-specific IGF-I-deficient (LID) plus ALS knockout (KO) mice] [20] also leads to defects in wholebody and long bone length that are ameliorated by exogenous IGF-I treatment [20], further supporting an endocrine role for IGF-I in bone. Moreover, mice with a systemic IGF-I gene knockout also exhibit impaired bone formation [21] and show a minimal anabolic response to intermittent treatment with parathyroid hormone (PTH) [21], which normally stimulates increases in bone mineral density [22, 23]. As PTH induces IGF-I messenger RNA (mRNA) and protein expression in osteoblasts [24], these latter results highlight a role for locally produced IGF-I in mediating some of the actions of PTH in bone [21] and are consistent with the modified somatomedin hypothesis, which emphasizes autocrine and paracrine IGF actions [2-4]. Other experimental models have provided additional support for direct effects of IGFs in bone growth. As an example, targeted 
overexpression of IGF-I in osteoblasts in transgenic mice caused a doubling of the rate of bone formation in the distal femur and increased the volume of trabecular bone [25]. Taken together, these observations demonstrate key roles for systemic GH and IGF-I in bone formation and osteoblast function and show that agents such as PTH depend in part on local production of IGF-I to mediate bone growth.

GH and IGF actions also are important for normal skeletal muscle growth and repair. Mice lacking IGF-I or the IGF-I receptor have severely diminished muscle mass [17, 26], and mice deficient in the GH receptor also have muscle defects [27]. Similarly, transgenic mice expressing a dominant-negative IGF-I receptor in muscle exhibited a decrease in muscle mass and strength that was compensated in part by increased numbers of myonuclei per muscle fiber [28]. In contrast, overexpression of IGF-I in muscle of transgenic mice caused muscle fiber hypertrophy [29], prevented muscle loss during aging [30-32], and compensated for the decline in muscle mass seen in experimental muscular dystrophy [33]. Other evidence suggests that locally derived IGFs facilitate muscle repair both after injury and in response to increased muscle force and work. IGF-I mRNA and protein have been detected in replicating myoblasts after ischemic or toxic injury [34,35], and expression of IGF-I and IGF-II were increased as early events in work-induced muscle hypertrophy [36, 37]. Thus, sustained local GH and IGF actions are important for muscle growth, maintenance, repair, and regeneration.

\section{GH signaling and actions}

\section{GH-activated signal transduction pathways}

A single GH molecule binds sequentially with high affinity to the extracellular domains of two GH receptors [38], leading to rapid activation of receptor-associated intracellular tyrosine protein kinase Jak2 $[39,40]$. Jak2 then initiates a series of protein phosphorylation steps that culminate in induction of several intracellular signaling networks, including the Ras - Raf - Mek - Erk and PI3-kinase - Akt pathways [39, 40]. Among downstream signaling molecules acutely activated by the $\mathrm{GH}$ receptor and Jak2 are several transcription factors [41], including members of the Stat family [42], and these proteins in turn are responsible for many of the effects of GH on gene expression [41, 42]. Stats were identified originally as components of interferon (IFN)- $\alpha$ - and IFN- $\gamma$-signaling pathways [43] and are now known to be activated in response to many cytokines and hormones, including GH [39, 40]. GH induces Stats 1,3,5a, and 5b in a variety of cell types [44-50]. Once activated, these factors form homodimers (and heterodimers for Stats 1 and 3), enter the nucleus, and bind to response elements in the chromosomal DNA of a range of target genes [43].

\section{Stats and $\mathrm{GH}$ actions}

The putative roles of Stats in mediating GH-regulated somatic growth were investigated initially in gene knockout experiments in mice. Inactivation of Stat 1 did not alter growth, and Stat3 deficiency caused early embryonic death (reviewed in [43]). Joint knockout of Stat5a and Stat5b impaired growth of male and female mice to 60-70\% of wild type and led to a $50 \%$ decline in serum IGF-I levels [51]. Stat5b deficiency alone was associated with an $\sim 20 \%$ decrease in postnatal growth and to diminished IGF-I levels in male mice but had no 
effect on growth rates or IGF-I in females [51, 52]. Subsequent studies investigating potentially novel causes of growth defects in children identified inactivating mutations of Stat5b as the responsible molecular lesions [53-55]. In addition to clinical features consistent with severe phenotypic GH-deficiency, these individuals also appear to have immunological dysfunction that is manifested in part by recurrent and chronic infections [55]. Other more biochemical experiments directly connected GH-activated Stat5b to induction of IGF-I and other gene transcription (see below).

\section{GH actions and gene regulation}

\section{Gene activation by GH}

Several studies have begun to catalog genes activated by GH under a variety of different experimental situations [56-61], and efforts have been initiated to identify transcription factors responsible for induction of each GH-regulated gene, although in several of these studies, it has not been established whether GH is acting at transcriptional or posttranscriptional steps (e.g. to alter mRNA stability). In publications in which investigators employed mRNA profiling to define GH-regulated gene expression, variably sized cohorts of genes appear to be activated by GH, and with different kinetics. For example, in the 3T3 adipocyte cell culture model, Huo et al. found that GH induced the expression of 13 transcripts at 30 min but only two mRNAs at $4 \mathrm{~h}$ [59]. In contrast, 37 transcripts were up-regulated after $48 \mathrm{~h}$ of hormone exposure [59], suggesting that secondary signaling pathways are activated during chronic GH treatment. Similarly, Thompson et al. found that only eight genes were stimulated by GH in the liver within $3 \mathrm{~h}$ of a single hormone injection into GH-deficient rats [56], whereas Vidal et al. measured 52 hepatic mRNAs that increased in abundance by $2 \mathrm{~h}$ after GH treatment [60]. Of this latter group of acutely GH-activated genes, $20 \%$ appeared to be dependent on Stat5b [60], and one of these genes was IGF-I (see below).

No comparable studies have been performed in humans. However, when given as a single bolus or short-term infusion to healthy individuals, $\mathrm{GH}$ is able to acutely stimulate gene expression, including inducing mRNAs for suppressor of cytokine signaling (SOCS)-1, -2 , and -3 in both muscle and fat, and for IGF-I in muscle [62, 63].

In several mammalian species, most notably rodents, the pattern of GH secretion from the pituitary exerts a significant impact on gene expression in the liver and other tissues [64]. In the rat, adult males secrete $\mathrm{GH}$ in a highly pulsatile way, leading to peaks and troughs of plasma GH levels, whereas in females, in which GH secretion is more continuous, plasma hormone levels are relatively constant [64]. These gender-specific differences in exposure of cells to GH lead to sexually dimorphic programs of gene expression. Using gene expression profiling, Wauthier and Waxman showed that GH deficiency eliminated most of these differences [65], whereas Ahluwalia et al. found that 44/49 mRNAs whose levels of expression were higher in the liver of male versus female rats were reduced to female levels after 7 days of continuous (female pattern) GH treatment [66], implying that the chronic pattern of GH signaling has a significant impact on gene regulation. 


\section{Gene repression by GH}

As GH plays a central role in controlling somatic growth, tissue repair and regeneration, intermediary metabolism, and other biological actions, it is not surprising the GH-activated signaling leads to both induction and inhibition of gene expression. Only recently have experiments addressed potential mechanisms by which GH impairs gene expression. Using GH-receptor-deficient mice as the model, Rowland et al. found that the chronic absence of GH signaling led to alterations in the abundance of 330 hepatic genes compared with receptor-intact control mice, with 269 transcripts being increased and 61 being reduced [58]. These results clearly illustrate that GH-mediated signaling exerts a significant inhibitory effect on gene expression, but they do not illumine the relevant biochemical or molecular mechanisms. Zhou and Waxman were the first to show that Stat5b could function as a GHinduced repressor of gene expression. They found that genes induced by several other transcription factors, including peroxisome proliferator-activated receptor (PPAR)- $\alpha,-\gamma$, and $-\delta$ and the thyroid hormone receptor were inhibited by Stat5b [67, 68]. Using a global gene expression profiling approach, we subsequently demonstrated that Stat5b appeared to be responsible for the vast majority of genes acutely repressed by GH in the liver of rats (89/97 genes inhibited by GH within $2 \mathrm{~h}$ of hormone treatment were Stat5b-dependent [69]). Among these GH-inhibited hepatic genes was IGFBP-1, which encodes IGF binding protein-1, a modulator of the bioavailability of IGF-I in the blood $[3,70]$. We found that GH-activated Stat5b repressed IGFBP-1 gene transcription by interfering with the actions of forkhead box O1 (FoxO1), which is the major transcriptional inducer of IGFBP-1 [71]. The biochemical mechanisms by which GH inhibits IGFBP-1 gene expression thus differ from those of insulin, which represses IGFBP-1 gene transcription through activation of Akt, which phosphorylates FoxO1, thus causing its exit from the nucleus [71, 72]. Bioinformatic analysis of the 89 genes inhibited by GH via Stat5b revealed that only 20\% contained putative FoxO1 binding sites in their gene promoters [69], indicating that interference with FoxO1 is only one of several potential mechanisms of gene inhibition by Stat5b. Studies by Clodfelter et al. also concluded that Stat5b could repress gene expression, as they found that the abundance of several hundred mRNAs was increased in the liver of mice lacking this transcription factor compared with wild-type controls [61].

\section{Regulation of IGF-I gene expression by GH}

\section{IGF-I protein and gene structure}

IGF-I is a single-chain 70 amino acid peptide with a highly conserved amino acid sequence and a complicated and conserved gene structure (reviewed in [73]). In mammals, the singlecopy IGF-I gene, located on chromosome 12 in humans, consists of six exons and five introns and spans more than $80 \mathrm{~kb}$ of chromosomal DNA [73]. IGF-I gene expression is governed by several biochemical mechanisms that lead to the production of multiple IGF-I mRNAs through the combination of distinct promoter use, variable transcription start sites, alternative RNA splicing, and differential RNA polyadenylation (reviewed in [73]). In mammals, individual promoters reside $5^{\prime}$ to IGF-I exons 1 and 2 (P1 and P2, respectively), whereas in nonmammalian vertebrates, a single promoter is adjacent to exon 1. P1, the major promoter in mammals, is active in all tissues in which IGF-I is expressed [74, 75]. P1 regulates IGF-I transcripts containing exon 1, and nucleotide sequences of rat and human 
exon 1 also are very similar to each other (95\% identity), as is exon 1 of other species [74, 76-78]. Exon 1 contains the $5^{\prime}$ nontranslated region of IGF-I mRNA and the first 21 codons of the IGF-I signal peptide. P2 governs transcripts containing exon 2 and is active primarily in the liver, where it is responsible for $\sim 25 \%$ of IGF-I mRNAs under normal physiological conditions [75, 79]. Exon 2 also encodes a $5^{\prime}$ nontranslated region and the initial six codons for an alternative signal peptide [73]. Both $\mathrm{P} 1$ and $\mathrm{P} 2$ regulate transcription over dispersed start sites [73], and GH activates both promoters to an equivalent extent in the liver [80, 81]. In mammals IGF-I transcripts containing either exons 1 or 2 are spliced onto exon 3 [73]. Exon 3 encodes the distal common 27 amino acids of the signal peptide and the first 25 amino acids of mature IGF-I. The remainder of 70 residue IGF-I is located in exon 4, which also contains the common part of two distinct carboxylic acid ( $\mathrm{COOH})$-terminal peptide extensions that are found in IGF-I precursor proteins (E domains [73]). Interested readers are referred to a more comprehensive review of IGF-I gene and protein structure [73].

\section{Stat5b and control of IGF-I gene transcription by GH}

It has been known for many years that GH rapidly and potently induces IGF-I gene transcription in vivo $[82,83]$. Despite this knowledge and despite much effort by several groups, the use of conventional assays of promoter function and DNA protein-binding studies has yielded little about biochemical mechanisms of IGF-I gene activation by GH beyond identification of promoter elements needed for basal transcriptional control [84-87]. The only molecular clue to regulation by GH was identification of a GHstimulated alteration in chromatin structure in the second IGF-I intron by our group [82, 83]. This single GHregulated DNase-I hypersensitive site (HS7) appeared just prior to induction of IGF-I gene transcription by GH and disappeared coincident with the fall in IGF-I transcription by $\sim 6 \mathrm{~h}$ after single hormone pulse to GH-deficient rats [82, 83]. Subsequent studies with recombinant adenoviruses expressing modified versions of rat Stat5b showed that a dominant-negative Stat5b completely blocked GH-induced IGF-I gene transcription in the liver of rats and prevented accumulation of IGF-I mRNA, whereas a constitutively active Stat5b stimulated IGF-I gene expression even in the absence of GH [80, 81]. Based on these observations, we soon identified two adjacent putative Stat5 binding sites in the HS7 region of the rat IGF-I gene that were conserved in IGF-I genes from other mammalian species, and we showed that GH rapidly induced binding of Stat5b to this DNA segment in vivo, with onset just prior to initiation of IGF-I gene transcription from both promoters in the liver [80, 81]. Subsequent experiments by our group and others have mapped several potential Stat5b binding sites to chromatin within both the rat and human IGF-I loci [88-90]. Taken together, these observations provide a framework for elucidating the biochemical mechanisms by which GH induces IGF-I gene transcription through Stat5b under normal physiological conditions. Figures 1 and 2 present an outline of mechanisms of regulation of gene expression by $\mathrm{GH}$.

\section{Summary and conclusions}

GH and IGF-I play multiple roles in human and animal physiology and disease. They are essential for normal preand postnatal growth and are key factors in normal tissue repair and regeneration throughout the lifespan. Conversely, actions of GH and IGF-I have been linked 
to accelerated aging and to cancer development and metastasis. A more comprehensive understanding of the basic biochemistry and molecular biology of GH and IGF-I actions is needed to devise ways to separate therapeutically useful from deleterious effects of this potent hormonal signaling system.

\section{Acknowledgments}

Research cited from our laboratory was supported by grants from the US National Institutes of Health (R01 DK069703 to PR, and K08 DK077897 to DJC).

\section{References}

1. Salmon WD, Daughaday WH. A hormonally controlled serum factor which stimulates sulfate incorporation by cartilage in vitro. J Lab Clin Med. 1957; 49:825-836. [PubMed: 13429201]

2. Daughaday WH, Rotwein P. Insulin-like growth factors I and II. Peptide, messenger ribonucleic acid and gene structures, serum, and tissue concentrations. Endocr Rev. 1989; 10:68-91. [PubMed: 2666112]

3. Jones JI, Clemmons DR. Insulin-like growth factors and their binding proteins: biological actions. Endocr Rev. 1995; 16:3-34. [PubMed: 7758431]

4. Le Roith D, Bondy C, Yakar S, Liu JL, Butler A. The somatomedin hypothesis: 2001. Endocr Rev. 2001; 22:53-74. [PubMed: 11159816]

5. Melmed, S. Endocrinology. 5th edn.. Philadelphia: Elsevier Saunders; 2006. p. 411-428.

6. Frank RN. Diabetic retinopathy. N Engl J Med. 2004; 350:48-58. [PubMed: 14702427]

7. Tatar M, Bartke A, Antebi A. The endocrine regulation of aging by insulin-like signals. Science. 2003; 299:1346-1351. [PubMed: 12610294]

8. Ibrahim YH, Yee D. Insulin-like growth factor-I and cancer risk. Growth Horm IGF Res. 2004; 14:261-269. [PubMed: 15231294]

9. Laban C, Bustin SA, Jenkins PJ. The GH-IGF-I axis and breast cancer. Trends Endocrinol Metab. 2003; 14:28-34. [PubMed: 12475609]

10. Pollak M. Insulin and insulin-like growth factor signalling in neoplasia. Nat Rev Cancer. 2008; 8:915-928. [PubMed: 19029956]

11. Mayo KE. A little lesson in growth regulation. Nat Genet. 1996; 12:8-9. [PubMed: 8528257]

12. Rosenfeld RG, Rosenbloom AL, Guevara-Aguirre J. Growth hormone (GH) insensitivity due to primary GH receptor deficiency. Endocr Rev. 1994; 15:369-390. [PubMed: 8076588]

13. Goddard AD, Covello R, Luoh SM, Clackson T, Attie KM, Gesundheit N, Rundle AC, Wells JA, Carlsson LM. Mutations of the growth hormone receptor in children with idiopathic short stature. The Growth Hormone Insensitivity Study Group. N Engl J Med. 1995; 333:1093-1098. [PubMed: 7565946]

14. Abuzzahab MJ, Schneider A, Goddard A, Grigorescu F, Lautier C, Keller E, Kiess W, Klammt J, Kratzsch J, Osgood D, Pfaffle R, Raile K, Seidel B, Smith RJ, Chernausek SD. IGF-I receptor mutations resulting in intrauterine and postnatal growth retardation. N Engl J Med. 2003; 349:2211-2222. [PubMed: 14657428]

15. Woods KA, Camacho-Hubner C, Savage MO, Clark AJ. Intrauterine growth retardation and postnatal growth failure associated with deletion of the insulin-like growth factor I gene. N Engl J Med. 1996; 335:1363-1367. [PubMed: 8857020]

16. Lupu F, Terwilliger JD, Lee K, Segre GV, Efstratiadis A. Roles of growth hormone and insulinlike growth factor 1 in mouse postnatal growth. Dev Biol. 2001; 229:141-162. [PubMed: 11133160]

17. Liu JP, Baker J, Perkins AS, Robertson EJ, Efstratiadis A. Mice carrying null mutations of the genes encoding insulin-like growth factor I (Igf-1) and type 1 IGF receptor (Igf1r). Cell. 1993; 75:59-72. [PubMed: 8402901]

18. Zhou Y, Xu BC, Maheshwari HG, He L, Reed M, Lozykowski M, Okada S, Cataldo L, Coschigamo K, Wagner TE, Baumann G, Kopchick JJ. A mammalian model for Laron syndrome 
produced by targeted disruption of the mouse growth hormone receptor/binding protein gene (the Laron mouse). Proc Natl Acad Sci U S A. 1997; 94:13215-13220. [PubMed: 9371826]

19. Sims NA, Clement-Lacroix P, Da Ponte F, Bouali Y, Binart N, Moriggl R, Goffin V, Coschigano K, Gaillard-Kelly M, Kopchick J, Baron R, Kelly PA. Bone homeostasis in growth hormone receptor-null mice is restored by IGF-I but independent of Stat5. J Clin Invest. 2000; 106:10951103. [PubMed: 11067862]

20. Yakar S, Rosen CJ, Beamer WG, Ackert-Bicknell CL, Wu Y, Liu JL, Ooi GT, Setser J, Frystyk J, Boisclair YR, LeRoith D. Circulating levels of IGF-1 directly regulate bone growth and density. J Clin Invest. 2002; 110:771-781. [PubMed: 12235108]

21. Miyakoshi N, Kasukawa Y, Linkhart TA, Baylink DJ, Mohan S. Evidence that anabolic effects of PTH on bone require IGF-I in growing mice. Endocrinology. 2001; 142:4349-4356. [PubMed: 11564695]

22. Neer RM, Arnaud CD, Zanchetta JR, Prince R, Gaich GA, Reginster JY, Hodsman AB, Eriksen EF, Ish-Shalom S, Genant HK, Wang O, Mitlak BH. Effect of parathyroid hormone (1-34) on fractures and bone mineral density in postmenopausal women with osteoporosis. N Engl J Med. 2001; 344:1434-1441. [PubMed: 11346808]

23. Ishizuya T, Yokose S, Hori M, Noda T, Suda T, Yoshiki S, Yamaguchi A. Parathyroid hormone exerts disparate effects on osteoblast differentiation depending on exposure time in rat osteoblastic cells. J Clin Invest. 1997; 99:2961-2970. [PubMed: 9185520]

24. McCarthy TL, Centrella M, Canalis E. Parathyroid hormone enhances the transcript and polypeptide levels of insulin-like growth factor I in osteoblast-enriched cultures from fetal rat bone. Endocrinology. 1989; 124:1247-1253. [PubMed: 2645113]

25. Zhao G, Monier-Faugere MC, Langub MC, Geng Z, Nakayama T, Pike JW, Chernausek SD, Rosen CJ, Donahue LR, Malluche HH, Fagin JA, Clemens TL. Targeted overexpression of insulin-like growth factor I to osteoblasts of transgenic mice: increased trabecular bone volume without increased osteoblast proliferation. Endocrinology. 2000; 141:2674-2682. [PubMed: 10875273]

26. Powell-Braxton L, Hollingshead P, Warburton C, Dowd M, Pitts-Meek S, Dalton D, Gillett N, Stewart TA. IGF-I is required for normal embryonic growth in mice. Genes Dev. 1993; 7:26092617. [PubMed: 8276243]

27. Sotiropoulos A, Ohanna M, Kedzia C, Menon RK, Kopchick JJ, Kelly PA, Pende M. Growth hormone promotes skeletal muscle cell fusion independent of insulin-like growth factor 1 upregulation. Proc Natl Acad Sci U S A. 2006; 103:7315-7320. [PubMed: 16670201]

28. Fernandez AM, Dupont J, Farrar RP, Lee S, Stannard B, Le Roith D. Muscle-specific inactivation of the IGF-I receptor induces compensatory hyperplasia in skeletal muscle. J Clin Invest. 2002; 109:347-355. [PubMed: 11827994]

29. Coleman ME, DeMayo F, Yin KC, Lee HM, Geske R, Montgomery C, Schwartz RJ. Myogenic vector expression of insulin-like growth factor I stimulates muscle cell differentiation and myofiber hypertrophy in transgenic mice. J Biol Chem. 1995; 270:12109-12116. [PubMed: 7744859]

30. Barton-Davis ER, Shoturma DI, Musaro A, Rosenthal N, Sweeney HL. Viral mediated expression of insulin-like growth factor I blocks the aging-related loss of skeletal muscle function. Proc Natl Acad Sci U S A. 1998; 95:15603-15607. [PubMed: 9861016]

31. Bodine SC, Stitt TN, Gonzalez M, Kline WO, Stover GL, Bauerlein R, Zlotchenko E, Scrimgeour A, Lawrence JC, Glass DJ, Yancopoulos GD. Akt/mTOR pathway is a crucial regulator of skeletal muscle hypertrophy and can prevent muscle atrophy in vivo. Nat Cell Biol. 2001; 3:1014-1019. [PubMed: 11715023]

32. Musaro A, McCullagh K, Paul A, Houghton L, Dobrowolny G, Molinaro M, Barton ER, Sweeney HL, Rosenthal N. Localized Igf-1 transgene expression sustains hypertrophy and regeneration in senescent skeletal muscle. Nat Genet. 2001; 27:195-200. [PubMed: 11175789]

33. Barton ER, Morris L, Musaro A, Rosenthal N, Sweeney HL. Muscle-specific expression of insulinlike growth factor I counters muscle decline in mdx mice. J Cell Biol. 2002; 157:137- 148. [PubMed: 11927606] 
34. Caroni P, Schneider C. Signaling by insulin-like growth factors in paralyzed skeletal muscle: rapid induction of IGF1 expression in muscle fibers and prevention of interstitial cell proliferation by IGF-BP5 and IGF-BP4. J Neurosci. 1994; 14:3378-3388. [PubMed: 7514217]

35. Edwall D, Schalling M, Jennische E, Norstedt G. Induction of insulin-like growth factor I messenger ribonucleic acid during regeneration of rat skeletal muscle. Endocrinology. 1989; 124:820-825. [PubMed: 2912704]

36. DeVol DL, Rotwein P, Sadow JL, Novakofski J, Bechtel PJ. Activation of insulin-like growth factor gene expression during work-induced skeletal muscle growth. Am J Physiol. 1990; 259:E89-E95. [PubMed: 2372054]

37. Carson JA, Nettleton D, Reecy JM. Differential gene expression in the rat soleus muscle during early work overload-induced hypertrophy. FASEB J. 2002; 16:207-209. [PubMed: 11744623]

38. Waters MJ, Hoang HN, Fairlie DP, Pelekanos RA, Brown RJ. New insights into growth hormone action. J Mol Endocrinol. 2006; 36:1-7. [PubMed: 16461922]

39. Herrington J, Carter-Su C. Signaling pathways activated by the growth hormone receptor. Trends Endocrinol Metab. 2001; 12:252-257. [PubMed: 11445442]

40. Lanning NJ, Carter-Su C. Recent advances in growth hormone signaling. Rev Endocr Metab Disord. 2006; 7:225-235. [PubMed: 17308965]

41. Rotwein P, Thomas MJ, Harris DM, Gronowski AM, LeStunff C. Nuclear actions of growth hormone: an in vivo perspective. J Anim Sci. 1997; 75:11-19.

42. Herrington J, Smit LS, Schwartz J, Carter-Su C. The role of STAT proteins in growth hormone signaling. Oncogene. 2000; 19:2585-2597. [PubMed: 10851057]

43. Levy DE, Darnell JEJ. Stats: transcriptional control and biological impact. Nat Rev Mol Cell Biol. 2002; 3:651-662. [PubMed: 12209125]

44. Gronowski AM, Rotwein P. Rapid changes in nuclear protein tyrosine phosphorylation after growth hormone treatment in vivo. Identification of phosphorylated mitogen-activated protein kinase and STAT91. J Biol Chem. 1994; 269:7874-7878. [PubMed: 7510676]

45. Gronowski AM, Zhong Z, Wen Z, Thomas MJ, Darnell JEJ, Rotwein P. In vivo growth hormone treatment rapidly stimulates the tyrosine phosphorylation and activation of Stat3. Mol Endocrinol. 1995; 9:171-177. [PubMed: 7776967]

46. Ram PA, Park SH, Choi HK, Waxman DJ. Growth hormone activation of Stat 1, Stat 3, and Stat 5 in rat liver. Differential kinetics of hormone desensitization and growth hormone stimulation of both tyrosine phosphorylation and serine/threonine phosphorylation. J Biol Chem. 1996; 271:5929-5940. [PubMed: 8621467]

47. Campbell GS, Meyer DJ, Raz R, Levy DE, Schwartz J, Carter-Su C. Activation of acute phase response factor (APRF)/Stat3 transcription factor by growth hormone. J Biol Chem. 1995; 270:3974-3979. [PubMed: 7876144]

48. Smit LS, Vanderkuur JA, Stimage A, Han Y, Luo G, Yu-Lee LY, Schwartz J, Carter-Su C. Growth hormone-induced tyrosyl phosphorylation and deoxyribonucleic acid binding activity of Stat5A and Stat5B. Endocrinology. 1997; 138:3426-3434. [PubMed: 9231797]

49. Smit LS, Meyer DJ, Billestrup N, Norstedt G, Schwartz J, Carter-Su C. The role of the growth hormone $(\mathrm{GH})$ receptor and JAK1 and JAK2 kinases in the activation of Stats 1, 3, and 5 by GH. Mol Endocrinol. 1996; 10:519-533. [PubMed: 8732683]

50. Gebert CA, Park SH, Waxman DJ. Regulation of signal transducer and activator of transcription (STAT) 5 b activation by the temporal pattern of growth hormone stimulation. Mol Endocrinol. 1997; 11:400-414. [PubMed: 9092792]

51. Teglund S, McKay C, Schuetz E, van Deursen JM, Stravopodis D, Wang D, Brown M, Bodner S, Grosveld G, Ihle JN. Stat5a and Stat5b proteins have essential and nonessential, or redundant, roles in cytokine responses. Cell. 1998; 93:841-850. [PubMed: 9630227]

52. Udy GB, Towers RP, Snell RG, Wilkins RJ, Park SH, Ram PA, Waxman DJ, Davey HW. Requirement of STAT5b for sexual dimorphism of body growth rates and liver gene expression. Proc Natl Acad Sci U S A. 1997; 94:7239-7244. [PubMed: 9207075]

53. Kofoed EM, Hwa V, Little B, Woods KA, Buckway CK, Tsubaki J, Pratt KL, Bezrodnik L, Jasper H, Tepper A, Heinrich JJ, Rosenfeld RG. Growth hormone insensitivity associated with a STAT5b mutation. N Engl J Med. 2003; 349:1139-1147. [PubMed: 13679528] 
54. Hwa V, Little B, Adiyaman P, Kofoed EM, Pratt KL, Ocal G, Berberoglu M, Rosenfeld RG. Severe growth hormone insensitivity resulting from total absence of signal transducer and activator of transcription 5b. J Clin Endocrinol Metab. 2005; 90:4260-4266. [PubMed: 15827093]

55. Rosenfeld RG, Belgorosky A, Camacho-Hubner C, Savage MO, Wit JM, Hwa V. Defects in growth hormone receptor signaling. Trends Endocrinol Metab. 2007; 18:134-141. [PubMed: 17391978]

56. Thompson BJ, Shang CA, Waters MJ. Identification of genes induced by growth hormone in rat liver using cDNA arrays. Endocrinology. 2000; 141:4321-4324. [PubMed: 11089569]

57. Flores-Morales A, Stahlberg N, Tollet-Egnell P, Lundeberg J, Malek RL, Quackenbush J, Lee NH, Norstedt G. Microarray analysis of the in vivo effects of hypophysectomy and growth hormone treatment on gene expression in the rat. Endocrinology. 2001; 142:3163-3176. [PubMed: 11416039]

58. Rowland JE, Lichanska AM, Kerr LM, White M, d'Aniello EM, Maher SL, Brown R, Teasdale RD, Noakes PG, Waters MJ. In vivo analysis of growth hormone receptor signaling domains and their associated transcripts. Mol Cell Biol. 2005; 25:66-77. [PubMed: 15601831]

59. Huo JS, McEachin RC, Cui TX, Duggal NK, Hai T, States DJ, Schwartz J. Profiles of growth hormone $(\mathrm{GH})$-regulated genes reveal time-dependent responses and identify a mechanism for regulation of activating transcription factor 3 by GH. J Biol Chem. 2006; 281:4132-4141. [PubMed: 16326703]

60. Vidal OM, Merino R, Rico-Bautista E, Fernandez-Perez L, Chia DJ, Woelfle J, Ono M, Lenhard B, Norstedt G, Rotwein P, Flores-Morales A. In vivo transcript profiling and phylogenetic analysis identifies suppressor of cytokine signaling 2 as a direct signal transducer and activator of transcription 5b target in liver. Mol Endocrinol. 2007; 21:293-311. [PubMed: 17008382]

61. Clodfelter KH, Holloway MG, Hodor P, Park SH, Ray WJ, Waxman DJ. Sex-dependent liver gene expression is extensive and largely dependent upon signal transducer and activator of transcription $5 b$ (STAT5b): STAT5b-dependent activation of male genes and repression of female genes revealed by microarray analysis. Mol Endocrinol. 2006; 20:1333-1351. [PubMed: 16469768]

62. Jorgensen JO, Jessen N, Pedersen SB, Vestergaard E, Gormsen L, Lund SA, Billestrup N. GH receptor signaling in skeletal muscle and adipose tissue in human subjects following exposure to an intravenous GH bolus. Am J Physiol Endocrinol Metab. 2006; 291:E899-E905. [PubMed: 16757551]

63. Nielsen C, Gormsen LC, Jessen N, Pedersen SB, Moller N, Lund S, Jorgensen JO. Growth hormone signaling in vivo in human muscle and adipose tissue: impact of insulin, substrate background, and growth hormone receptor blockade. J Clin Endocrinol Metab. 2008; 93:28422850. [PubMed: 18460563]

64. Waxman DJ, O'Connor C. Growth hormone regulation of sex-dependent liver gene expression. Mol Endocrinol. 2006; 20:2613-2629. [PubMed: 16543404]

65. Wauthier V, Waxman DJ. Sex-specific early growth hormone response genes in rat liver. Mol Endocrinol. 2008; 22:1962-1974. [PubMed: 18483176]

66. Ahluwalia A, Clodfelter KH, Waxman DJ. Sexual dimorphism of rat liver gene expression: regulatory role of growth hormone revealed by deoxyribonucleic Acid microarray analysis. Mol Endocrinol. 2004; 18:747-760. [PubMed: 14684848]

67. Zhou YC, Waxman DJ. Cross-talk between janus kinase-signal transducer and activator of transcription (JAK-STAT) and peroxisome proliferator-activated receptor-alpha (PPARalpha) signaling pathways. Growth hormone inhibition of pparalpha transcriptional activity mediated by stat5b. J Biol Chem. 1999; 274:2672-2681. [PubMed: 9915797]

68. Zhou YC, Waxman DJ. STAT5b down-regulates peroxisome proliferator-activated receptor alpha transcription by inhibition of ligand-independent activation function region-1 transactivation domain. J Biol Chem. 1999; 274:29874-29882. [PubMed: 10514468]

69. Ono M, Chia DJ, Merino-Martinez R, Flores-Morales A, Unterman TG, Rotwein P. Signal transducer and activator of transcription (Stat) 5b-mediated inhibition of insulin-like growth factor binding protein-1 gene transcription: a mechanism for repression of gene expression by growth hormone. Mol Endocrinol. 2007; 21:1443-1457. [PubMed: 17426286] 
70. Murphy LJ. Insulin-like growth factor-binding proteins: functional diversity or redundancy? J Mol Endocrinol. 1998; 21:97-107. [PubMed: 9801453]

71. Barthel A, Schmoll D, Unterman TG. FoxO proteins in insulin action and metabolism. Trends Endocrinol Metab. 2005; 16:183-189. [PubMed: 15860415]

72. Accili D, Arden KC. FoxOs at the crossroads of cellular metabolism, differentiation, and transformation. Cell. 2004; 117:421-426. [PubMed: 15137936]

73. Rotwein, P. Contemporary endocrinology: the IGF system. Totowa: Humana Press; 1999. Molecular biology of IGF-I and IGF-II; p. 19-35.

74. Hall LJ, Kajimoto Y, Bichell D, Kim SW, James PL, Counts D, Nixon LJ, Tobin G, Rotwein P. Functional analysis of the rat insulin-like growth factor I gene and identification of an IGF-I gene promoter. DNA Cell Biol. 1992; 11:301-313. [PubMed: 1605853]

75. Adamo ML, Ben-Hur H, Roberts CTJ, LeRoith D. Regulation of start site usage in the leader exons of the rat insulin-like growth factor-I gene by development, fasting, and diabetes. Mol Endocrinol. 1991; 5:1677-1686. [PubMed: 1779970]

76. Shimatsu A, Rotwein P. Mosaic evolution of the insulin-like growth factors. Organization, sequence, and expression of the rat insulin-like growth factor I gene. J Biol Chem. 1987; 262:7894-7900. [PubMed: 3034909]

77. Kim SW, Lajara R, Rotwein P. Structure and function of a human insulin-like growth factor-I gene promoter. Mol Endocrinol. 1991; 5:1964-1972. [PubMed: 1791841]

78. Kavsan VM, Koval AP, Grebenjuk VA, Chan SJ, Steiner DF, Roberts CTJ, LeRoith D. Structure of the chum salmon insulin-like growth factor I gene. DNA Cell Biol. 1993; 12:729-737. [PubMed: 8397830]

79. Hoyt EC, Van Wyk JJ, Lund PK. Tissue and development specific regulation of a complex family of rat insulin-like growth factor I messenger ribonucleic acids. Mol Endocrinol. 1988; 2:10771086. [PubMed: 3221875]

80. Woelfle J, Billiard J, Rotwein P. Acute control of insulin-like growth factor-1 gene transcription by growth hormone through STAT5B. J Biol Chem. 2003; 278:22696-22702. [PubMed: 12682066]

81. Woelfle J, Chia DJ, Rotwein P. Mechanisms of growth hormone (GH) action. Identification of conserved Stat5 binding sites that mediate GH-induced insulin-like growth factor-I gene activation. J Biol Chem. 2003; 278:51261-51266. [PubMed: 14532269]

82. Bichell DP, Kikuchi K, Rotwein P. Growth hormone rapidly activates insulin-like growth factor I gene transcription in vivo. Mol Endocrinol. 1992; 6:1899-1908. [PubMed: 1480177]

83. Thomas MJ, Kikuchi K, Bichell DP, Rotwein P. Characterization of deoxyribonucleic acid-protein interactions at a growth hormone-inducible nuclease hypersensitive site in the rat insulin-like growth factor-I gene. Endocrinology. 1995; 136:562-569. [PubMed: 7835289]

84. An MR, Lowe WLJ. The major promoter of the rat insulin-like growth factor-I gene binds a protein complex that is required for basal expression. Mol Cell Endocrinol. 1995; 114:77-89. [PubMed: 8674854]

85. Mittanck DW, Kim SW, Rotwein P. Essential promoter elements are located within the 5' untranslated region of human insulin-like growth factor-I exon I. Mol Cell Endocrinol. 1997; 126:153-163. [PubMed: 9089653]

86. Wang L,Wang X, Adamo ML. Two putative GATA motifs in the proximal exon 1 promoter of the rat insulin-like growth factor I gene regulate basal promoter activity. Endocrinology. 2000; 141:1118-1126. [PubMed: 10698188]

87. Wang X, Talamantez JL, Adamo ML. A CACCC box in the proximal exon 2 promoter of the rat insulin-like growth factor I gene is required for basal promoter activity. Endocrinology. 1998; 139:1054-1066. [PubMed: 9492038]

88. Wang Y, Jiang H. Identification of a distal STAT5-binding DNA region that may mediate growth hormone regulation of insulin-like growth factor-I gene expression. J Biol Chem. 2005; 280:10955-10963. [PubMed: 15677453]

89. Chia DJ, Ono M, Woelfle J, Schlesinger-Massart M, Jiang H, Rotwein P. Characterization of distinct Stat5b binding sites that mediate growth hormone-stimulated IGF-I gene transcription. J Biol Chem. 2006; 281:3190-3197. [PubMed: 16339156] 
90. Eleswarapu S, Gu Z, Jiang H. Growth hormone regulation of insulin-like growth factor-I gene expression may be mediated by multiple distal signal transducer and activator of transcription 5 binding sites. Endocrinology. 2008; 149:2230-2240. [PubMed: 18276757] 


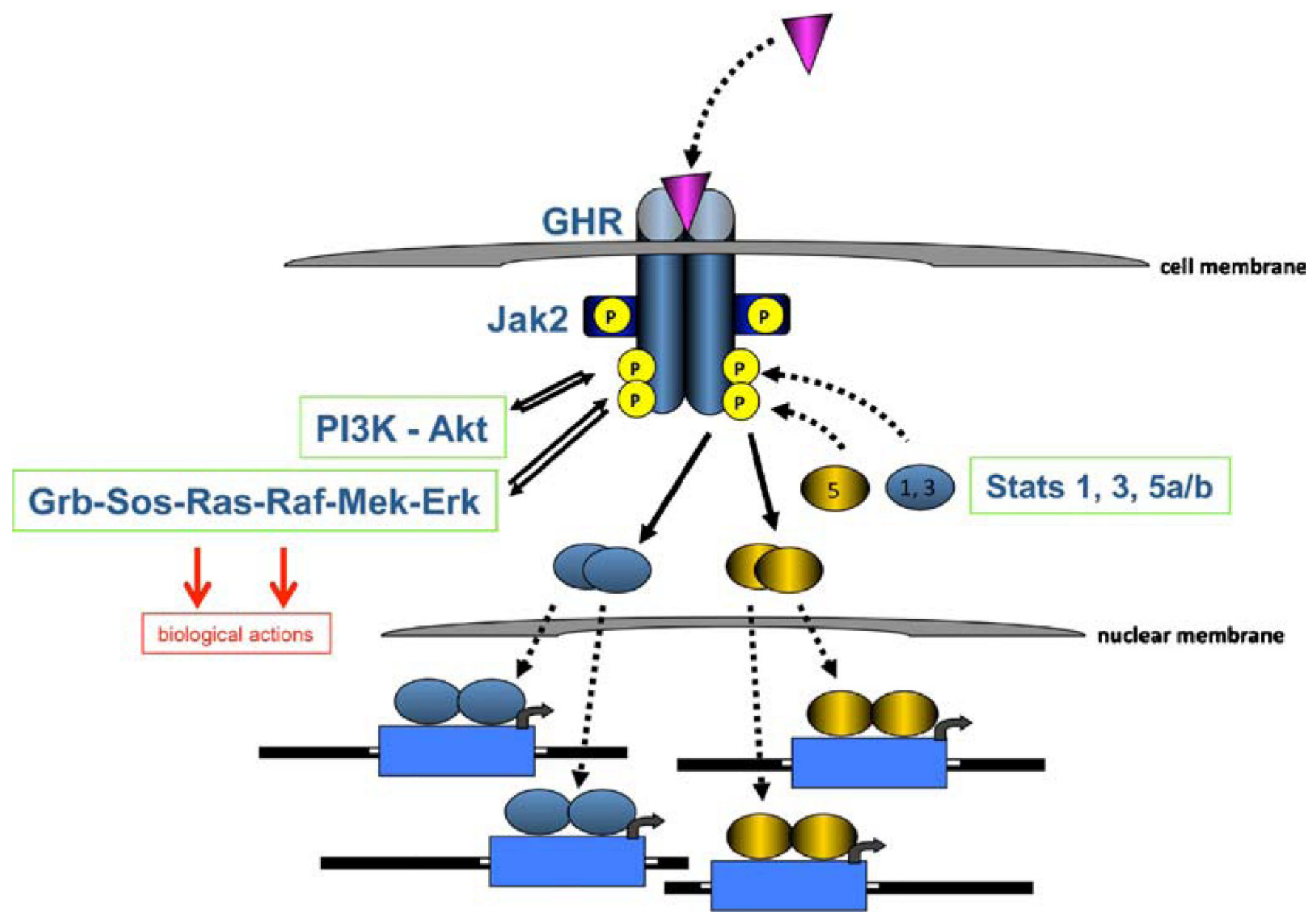

Fig. 1.

Schematic diagram of growth hormone $(\mathrm{GH})$ receptor signaling and gene activation. GH (purple triangle) binds to its receptor, causing both receptor dimerization and activation of the associated intracellular tyrosine kinase, Jak2, which phosphorylates itself and the GH receptor on tyrosine residues (each indicated as $P$ within a yellow circle). A series of intracellular signal transduction pathways are activated, which mediate the biological effects of GH. Signal transducer and activator of transcription (Stats) 1, 3, 5a, and 5b are recruited to the $\mathrm{GH}$ receptor and become tyrosine phosphorylated, leading to their dimerization and translocation into the nucleus, where they bind to DNA in chromatin of target genes and activate gene transcription (indicated by bent arrows at transcription start sites) 


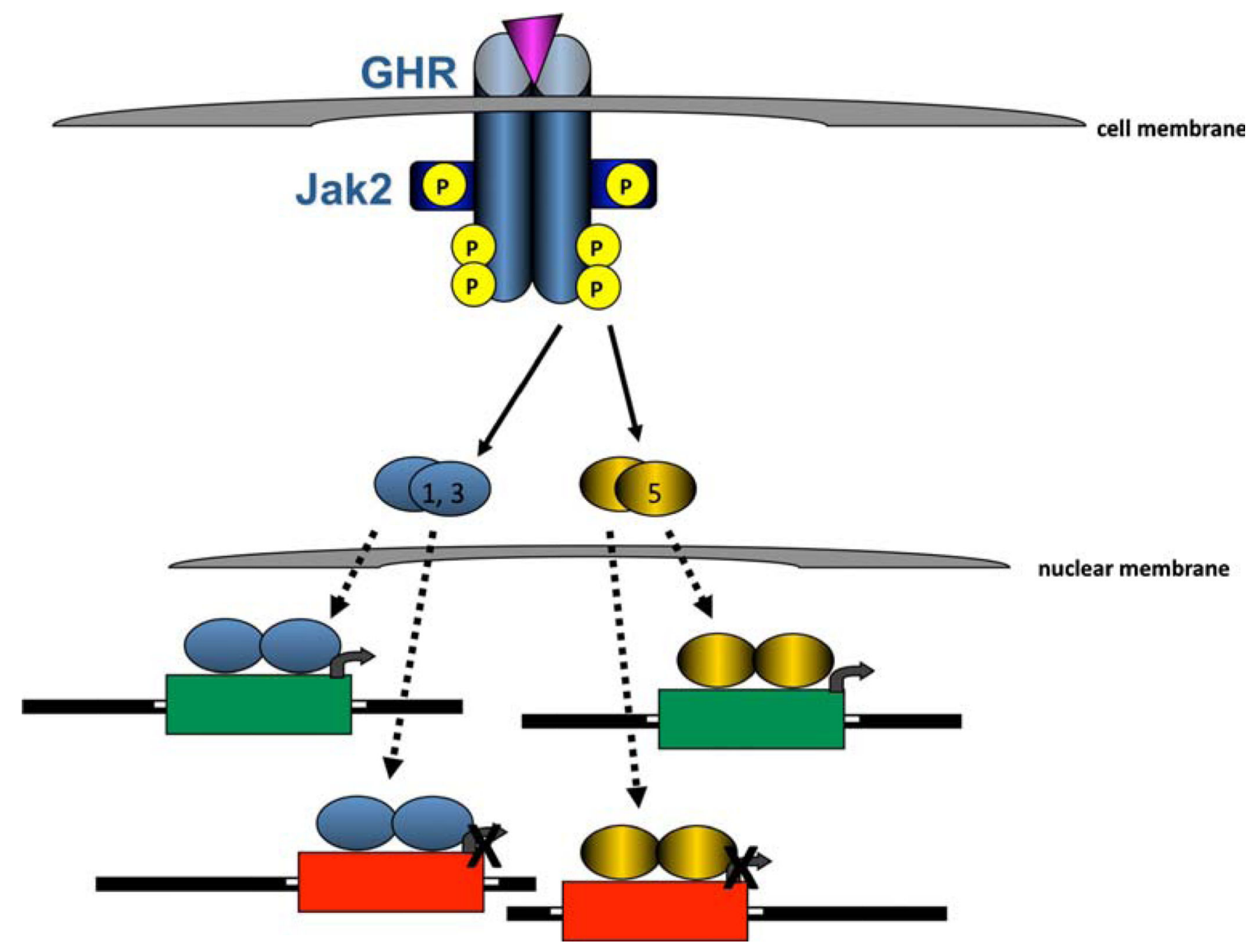

Fig. 2.

Signal transducer and activator of transcription (Stats) mediate growth hormone (GH)regulated gene activation and gene repression. Activated Stats 1, 3, 5a, and $5 \mathrm{~b}$ are translocated into the nucleus and bind to DNA in chromatin of target genes, where they can either activate gene transcription (indicated by bent arrows at transcription start sites; green boxes) or inhibit it (indicated by Xs overlying bent arrows at transcription start sites; red boxes) 